\title{
Aspirin in Sickle-Cell Anaemia
}

\begin{tabular}{|l|l|}
\hline N.O. & Osamo \\
\hline
\end{tabular}

\section{Ankara/Benin City}

Prof. N.O. Osamo, University of Benin, Benin City (Nigeria)

To the Editor,

I read with great enthusiasm the paper of Osamo et al., Therapeutic effect of aspirin in sickle-cell anaemia [Acta Haemat. 66: 102-107 (1981)]. It seems to be a simple approach in the handling of patients with sickle-cell anaemia.

In their discussion they stated that 'in this double-blind study by the administration of $1.2 \mathrm{~g}$ daily of soluble aspirin in divided doses to 50 patients ...' Then what was given to the control group in divided doses in addition to folic acid and paludrine? Was a double-blind study necessary for this kind of research since each patient's objective measurements following treatment were compared to their findings prior to the treatment (as in table I of their article).

Although in their detailed study $\mathrm{pH}, \mathrm{Pc} \theta 2$ and base excess were evaluated, the results of these determinations were not recorded. Might possible $\mathrm{pH}$ changes explain some of the alterations?

Received: October 27, 1981 Accepted: February 8, 1982

Sinasi Özsoylu, MD, Hacettepe University, Ankara (Turkey)

This letter was presented to Dr. Osamo whose answer follows:

To the Editor,

I write to reply to the questions asked by Dr. Özsoylu. First, he wonders why a double-blind control was done in this kind of study. The simple answer to this is that at the time of the study, we had no idea in what direction the results would lead us and it would have been a pity if at the end of the study, we had found that non-use of a double-blind procedure had invalidated our conclusions.

Secondly, the control group was given small tablets of glucose produced in our Pharmacy Department to resemble the aspirin tablets.

Thirdly, we did not report the parameters $\mathrm{pH}, \mathrm{Pc} \theta 2$, and base excess because, although the instrument measures these automatically, they were not appreciably altered. There were minor $\mathrm{pH}$ changes and we do not think that a $\mathrm{pH}$ change of less than 0.1 could lead to such a phenomenal rise in the haemoglobin level as from an average of 7.5 to $10 \mathrm{~g}$ in 6 weeks. In any case, $\mathrm{pH}$ changes were changes in whole blood as opposed to changes in the haemolysates which were used for electrophoresis and, therefore, could not affect the electrophoretic mobility. 